\title{
Indicators of long-term sustainability of hand hygiene improvement and barriers in healthcare settings worldwide
}

\author{
B Allegranzi $^{1 *}$, S Bagheri Nejad ${ }^{1}$, D Pittet $^{2}$ \\ From International Conference on Prevention \& Infection Control (ICPIC 2011) \\ Geneva, Switzerland. 29 June - 2 July 2011
}

\section{Introduction / objectives}

Implementation of the WHO multimodal hand hygiene (HH) improvement strategy was successfully tested in 8 pilot sites in 2006-2008 with a significant improvement in $\mathrm{HH}$ compliance and other indicators. Indicators of long-term sustainability and barriers were evaluated 2 years later.

\section{Methods}

Semi-structured telephone interviews with site coordinators were conducted in 2010 using a predefined set of questions to investigate the status of core activities of $\mathrm{HH}$ promotion and monitoring, barriers to improvement and indicators of long-term sustainability.

\section{Results}

All coordinators accepted to be interviewed. The following indicators of long-term sustainability were identified: extension of $\mathrm{HH}$ promotion hospital-wide in sites where only a limited number of wards were initially involved in implementation; regular repetitionof $\mathrm{HH}$ training and preparation of new educational tools; poster refreshment and development of new reminders; continuation of $\mathrm{HH}$ compliance monitoring at least annually in $7 / 8$ sites; national scale-up in 5/6 countries with no previous $\mathrm{HH}$ campaign. Barriers to long-term sustainability, especially in low-resource settings, were: resistance to behavioural change in some professional categories; high staff turnover and workload; understaffing; lack of dedicated human resources; discontinuation of support by leaders and of regular budget allocation, especially for alcoholbased handrub procurement.

${ }^{1}$ Patient Safety, World Health Organization, Geneva, Switzerland

Full list of author information is available at the end of the article

\section{Conclusion}

Long-term sustainability of the HH strategy was demonstrated by the continuation and reinforcement of core elements over time. Some identified barriers raise concerns and indicate the need for further improvement and some substantial changes, particularly in countries with limited resources.

\section{Disclosure of interest}

None declared.

\section{Author details}

${ }^{1}$ Patient Safety, World Health Organization, Geneva, Switzerland. ${ }^{2}$ University of Geneva Hospitals, Geneva, Switzerland.

Published: 29 June 2011

doi:10.1186/1753-6561-5-S6-P262

Cite this article as: Allegranzi et al:: Indicators of long-term sustainability of hand hygiene improvement and barriers in healthcare settings worldwide. BMC Proceedings 2011 5(Suppl 6):P262.

Submit your next manuscript to BioMed Central and take full advantage of:

- Convenient online submission

- Thorough peer review

- No space constraints or color figure charges

- Immediate publication on acceptance

- Inclusion in PubMed, CAS, Scopus and Google Scholar

- Research which is freely available for redistribution 